Document downloaded from:

http://hdl.handle.net/10251/56208

This paper must be cited as:

Mestre, S.; Sales, S.; Palacios, M.; Lorente, M.; Mallol, G.; Pérez-Herranz, V. (2013). Lowcost inorganic cation exchange membrane for electrodialysis: optimum processing temperature for the cation exchanger. Desalination and Water Treatment. 51(16-18):33173324. doi:10.1080/19443994.2012.749177.

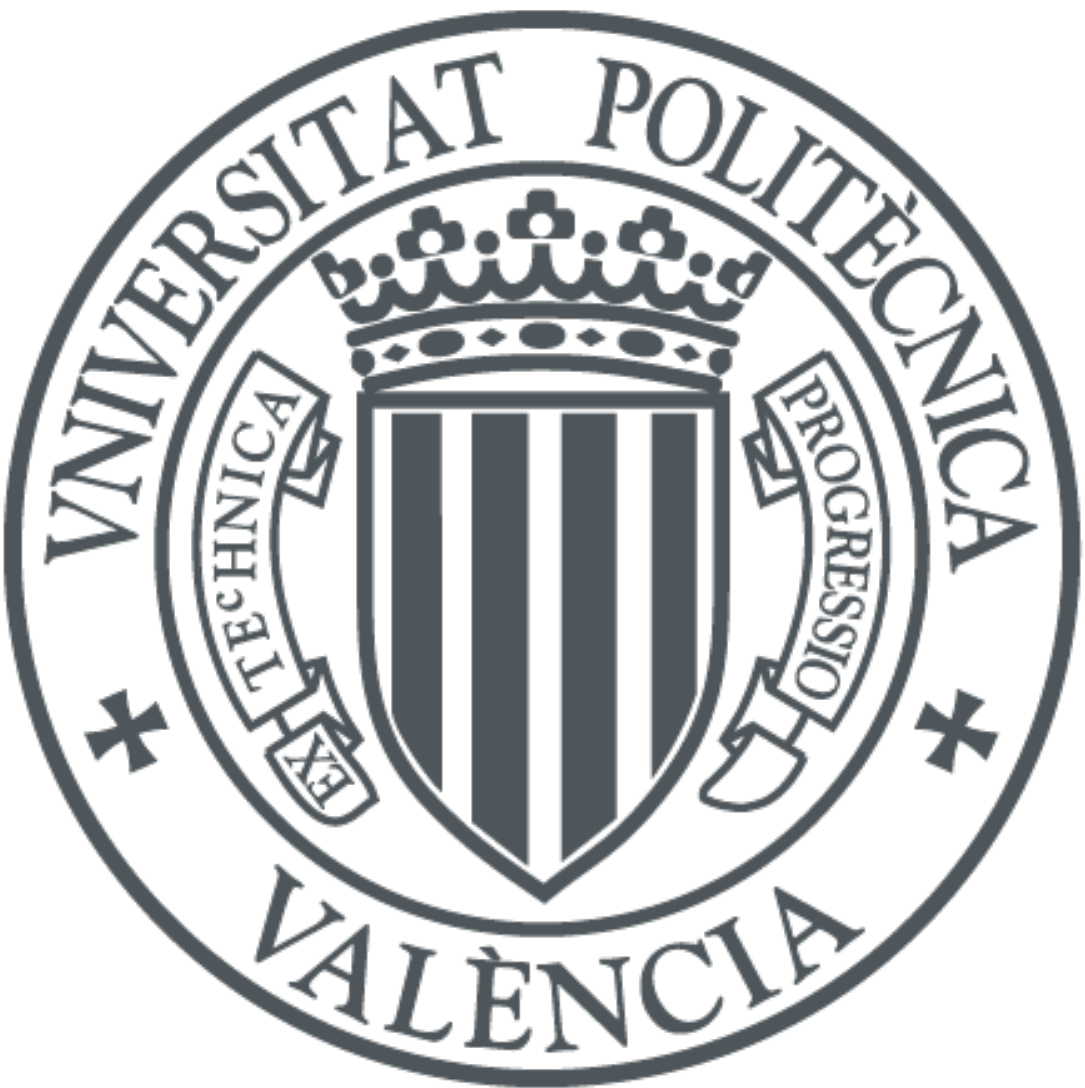

The final publication is available at

http://dx.doi.org/10.1080/19443994.2012.749177

Copyright Taylor \& Francis

Additional Information 


\title{
LOW-COST INORGANIC CATION-EXCHANGE MEMBRANE FOR ELECTRODIALYSIS: OPTIMUM PROCESSING TEMPERATURE FOR THE CATION EXCHANGER
}

\author{
S. MESTRE ${ }^{\mathrm{a}}$, S. SALES ${ }^{\mathrm{a}}$, M.D. PALACIOS ${ }^{\mathrm{a}}$, M.M. LORENTE ${ }^{\mathrm{a}}$, G. MALLOL ${ }^{\mathrm{a}}$, \\ V. PÉREZ-HERRANZ \\ anstituto de Tecnología Cerámica. Asociación de Investigación de las Industrias Cerámicas. \\ Universitat Jaume I. Av. Vicent Sos Baynat, s/n. 12006. Castellón. Spain. Tel. 34 \\ 964342425. Fax: 34964 342425. sergio.mestre@itc.uji.es. \\ bepartamento de Ingeniería Química y Nuclear. Universidad Politécnica de Valencia. \\ Camino de Vera s/n. 46022. Valencia. Spain. Tel.: 34 963877630. Fax: 34963877639.
}

\begin{abstract}
The optimum temperature for fixing zirconium phosphate, obtained by precipitation, on a low-cost ceramic support was determined in order to obtain an inorganic cation-exchange membrane for electrodialysis. Zirconium phosphate ion-exchange capacity maximised between $450^{\circ} \mathrm{C}$ and $550^{\circ} \mathrm{C}$, thus it was considered the optimum processing temperature. The origin of this maximum was investigated by means of XRD and TG-EGA. Zirconium phosphate formation by precipitation in the porous network of the support was verified by SEM-EDX and mercury intrusion porosimetry. The membrane obtained after thermal treatment at $450{ }^{\circ} \mathrm{C}$ displayed selectivity to the cations present in the spent rinse water of the chromium plating process. This property allows the recovery of chromium by removing the cations through the cation-exchange ceramic membrane.
\end{abstract}

Keywords: zirconium phosphate, ion-exchange capacity, cationic membrane, electrodialysis.

\section{Introduction}

Industrial applications of electrodialysis began around 1950 in the desalination of brackish water. Other processes subsequently reached an industrial scale, such as the production of acids and alkalis and the synthesis of chlorine and caustic soda [1]. In recent years, research has focused on the treatment of wastewater containing heavy metal ions, such as the tanning industry wastewater [2]. 
The key components of an electrodialysis unit are the ion-exchange membranes (anion, cation, or bipolar), which should ideally exhibit high permselectivity, low electrical resistance, good mechanical strength, and high thermal and chemical resistance [1]. The ionexchange membranes currently being manufactured are mainly polymeric membranes, in which the polymer itself either contains groups that are able to ionise (such as sulphonium, carboxyl, or quaternary ammonium) or the polymer acts as a support, in which an ionexchange resin is dispersed [3]. Although polymeric ion-exchange membranes perform well, they usually exhibit stability problems when they work in media with extreme $\mathrm{pH}$, at high temperatures, or in the presence of strong oxidisers or ionising radiations $[4,5]$.

Inorganic ion-exchange membranes were first developed in the nuclear industry, in order to work in the presence of radiations, and different synthesis methods have been put forward. Membranes were initially formed from ion exchangers in the form of powder agglomerated with organic binders (hydrated zirconium phosphate [4,6]; aluminium vanadate [7]; and tin, titanium, and zirconium phosphates [8] bound with polymers such as Teflon or Kynar). Two different lines were subsequently developed: one that deposited the inorganic ion exchanger in a porous organic matrix (zirconium phosphate in Nylon-6,6 [9], zirconium phosphate mixed with silicotungstic acid in polyvinylalcohol [10]) and another that deposited the exchanger in porous ceramic supports (hydrated zirconium oxide [11] or zirconium phosphate[12] deposited on an $\mathrm{Al}_{2} \mathrm{O}_{3}-\mathrm{ZrO}_{2}$ mixed support).

Studies in the literature have described ion removal from water by electrodialysis, using inorganic ion-exchange membranes [12-14]. The ability of such membranes to work in aggressive conditions theoretically allows treatment of troublesome industrial effluents. In particular, it might be possible to use inorganic ion-exchange membranes to treat the spent rinse water of the chrome plating process, in order to regenerate suitable water for washing the chrome plated products, as well as two streams with a high ion concentration, from which it might be possible to recover chromium and other metals.

In previous studies, the authors developed low-cost ceramic membranes for use as spacers in an electrochemical reactor for the recovery of spent chromium plating baths $[15,16]$. Judicious infiltration with inorganic ion exchangers, namely a cation and an anion exchanger, could enable these membranes to be used in an electrodialysis treatment of the spent rinse water of chrome plated products. Different cleaning operations could thus be performed of effluents from the chrome plating process, using different membranes made from the same ceramic support.

Hydrated zirconium phosphate is one of the most extensively researched cation exchangers and previous studies have described several synthesis methods [17-19], its allotropes [2022], as well as its different properties (ion-exchange capacity, thermal stability, ionic conductivity, and catalytic activity $[23,24]$ ). The simplest way of obtaining a zirconium 
phosphate-based inorganic cation-exchange membrane is by generating the exchanger in the porous network of a ceramic support and then fixing this by thermal treatment at a relatively low temperature $\left(200^{\circ} \mathrm{C}\right.$ according to Linkov et al. [12]). From a ceramic processing viewpoint, the higher the maximum thermal treatment temperature, the greater may the zirconium phosphate bonding strength to the ceramic support expected to be, though the ionexchange capacity could decrease notably since, above $735^{\circ} \mathrm{C}$, the stable phase is $\mathrm{ZrP}_{2} \mathrm{O}_{7}$, which has no ion-exchange capacity [25].

The present study was undertaken to determine the optimum temperature for fixing zirconium phosphate on a low-cost ceramic support in order to obtain an inorganic cationexchange membrane for electrodialysis. The membrane's ability to separate the anions and cations customarily present in the spent rinse water of the chrome plating process was verified.

\section{Experimental}

\subsection{Zirconium phosphate synthesis and membrane preparation}

Zirconium phosphate was synthesised by adapting the method described by Al-Othman [26]. $60 \mathrm{~g}$ of $\mathrm{ZrOCl}_{2} \cdot 8 \mathrm{H}_{2} \mathrm{O}$ (98\%, Aldrich) was dissolved in $1800 \mathrm{~cm}^{3}$ distilled water. $50 \mathrm{~cm}^{3}$ of $\mathrm{H}_{3} \mathrm{PO}_{4}(85 \%$, Fluka) was added dropwise to the resulting solution under constant stirring. The precipitate was left in contact with the mother liquid for 2 hours; it was then separated by filtration and washed with distilled water. The solid was dried in an oven at $110^{\circ} \mathrm{C}$ and wet milled with acetone in a ball mill using agate jars to reduce the particle size (Pulverisette 5, Fritsch GmbH, Germany). 5 g portions of dry material were thermally treated at different calcination temperatures $\left(T_{c}\right.$ between $150^{\circ}$ and $700^{\circ} \mathrm{C}$ ) in an electric furnace (HRF1200, Carbolite Furnaces Ltd, UK). The following thermal cycle was used: heating at $10^{\circ} \mathrm{C} / \mathrm{min}$ to maximum temperature, with a $30 \mathrm{~min}$ dwell at maximum temperature followed by natural cooling. The synthesis process of each sample was replicated three times to evaluate the reproducibility of the results.

The ceramic supports consisted of disks (50 $\mathrm{mm}$ in diameter and $8 \mathrm{~mm}$ thick), obtained from a mixture of kaolin and alumina, which were sintered for 6 hours at $1400^{\circ} \mathrm{C}$. The process has been described elsewhere $[15,16]$. The zirconium phosphate was deposited in four steps. First, the $\mathrm{ZrOCl}_{2}$ solution was infiltrated into the supports by capillary suction until the entire accessible porous network was filled. The infiltrated supports were then immersed in $\mathrm{H}_{3} \mathrm{PO}_{4}$ for 24 hours to produce zirconium phosphate precipitation. The supports were subsequently immersed in distilled water, the water being renewed several times until neutral reaction was reached. Finally, the supports were dried in an oven at $110^{\circ} \mathrm{C}$ and then heat-treated in the 
electric furnace using the same thermal cycle as that to which the cation exchanger had been subjected, this being deemed the optimum thermal cycle.

\subsection{Characterisation of zirconium phosphate}

The ion-exchange capacity was measured by adapting the method used by Helen et al. [27]. $0.5 \mathrm{~g}$ of each sample was dispersed in $100 \mathrm{~cm}^{3}$ of $0.05 \mathrm{M} \mathrm{NaCl}$, kept under magnetic stirring for 2 hours. The supernatant liquid was then titrated with $0.05 \mathrm{M} \mathrm{NaOH}$ and the ionexchange capacity (IEC) of $\mathrm{Na}^{+}$was calculated from the volume of consumed titrant required to reach $\mathrm{pH} 7$ from the equation:

$$
I E C=\frac{V \cdot C}{W}
$$

where IEC is the ion-exchange capacity (meq/g), $\mathrm{V}$ the added $\mathrm{NaOH}$ volume when the solution $\mathrm{pH}$ was $7\left(\mathrm{~cm}^{3}\right), \mathrm{C}$ the molar concentration of $\mathrm{NaOH}(\mathrm{mol} / \mathrm{L})$, and $\mathrm{W}$ the test sample mass $(\mathrm{g})$.

The evolution of the crystalline phases generated by the zirconium phosphate precipitate as a function of temperature was continuously measured by XRD (D8 Advance, Bruker AXS Inc, USA) combined with a high-temperature chamber (HTK1200N, Anton Paar GmbH, Germany). The thermal behaviour and volatiles released at each temperature were identified by TG-QMS (STA 449C and QMS 403C, Netzsch GmbH, Germany). The test was performed in air atmosphere at a heating rate of $10^{\circ} \mathrm{C} / \mathrm{min}$.

Membrane microstructure and composition were characterised by FEG-SEM (QUANTA 200F, FEI Co, USA) and EDX (PV6770/68-ME, EDAX, USA). Membrane pore size distribution was determined by mercury intrusion porosimetry (Autopore IV, Micromeritics, USA).

\subsection{Membrane electrochemical characterisation}

All reagents used in the experiments were analytical grade. Synthetic solutions simulating the composition of the chromium plating rinse water were prepared with $\mathrm{CrO}_{3}, \mathrm{NiSO}_{4}$ and $\mathrm{H}_{2} \mathrm{SO}_{4}$ (Panreac S.A.U. Spain), using distilled water. The concentrations used in the anodic compartment ranged from $10^{-4} \mathrm{M}$ to $10^{-2} \mathrm{M}$ for the $\mathrm{NiSO}_{4}$ solutions, from $10^{-3} \mathrm{M}$ to $10^{-2} \mathrm{M}$ for the $\mathrm{CrO}_{3}$ solutions and from $10^{-3} \mathrm{M}$ to $10^{-2} \mathrm{M}$ for the $\mathrm{H}_{2} \mathrm{SO}_{4}$ solutions. The cathodic compartment was filled with $\mathrm{H}_{2} \mathrm{SO}_{4}$ of the same concentration as the anodic compartment. The evolution of the nickel concentration with time was analysed using an atomic absorption spectrophotometer with a lamp current of $17 \mathrm{~mA}$ and a wavelength of $351.5 \mathrm{~nm}$ (AA Analyst 100, Perkin-Elmer Inc., USA). The evolution of the $\mathrm{Cr}(\mathrm{VI})$ concentration with time was colorimetrically determined using 1.5-diphenylcarbazide reagent analysed with a spectrometer (UV/Vis UV4, Unicam, The Netherlands). 
The experimental test rig consisted of an electrodialytic cell containing two PVC compartments separated by the ceramic membrane under study as shown in Figure 1. The effective area of the membranes was $14.14 \mathrm{~cm} 2$. The experiments were carried out at room temperature without stirring. The current was imposed between two graphite electrodes by a potentiostat/galvanostat (PGSTAT 20, Autolab B.V., The Netherlands). Two Ag/AgCl reference electrodes immersed in Luggin capillaries were installed to measure the voltage drop across the membrane. The membrane potential and the imposed current were registered using a PC data acquisition system.

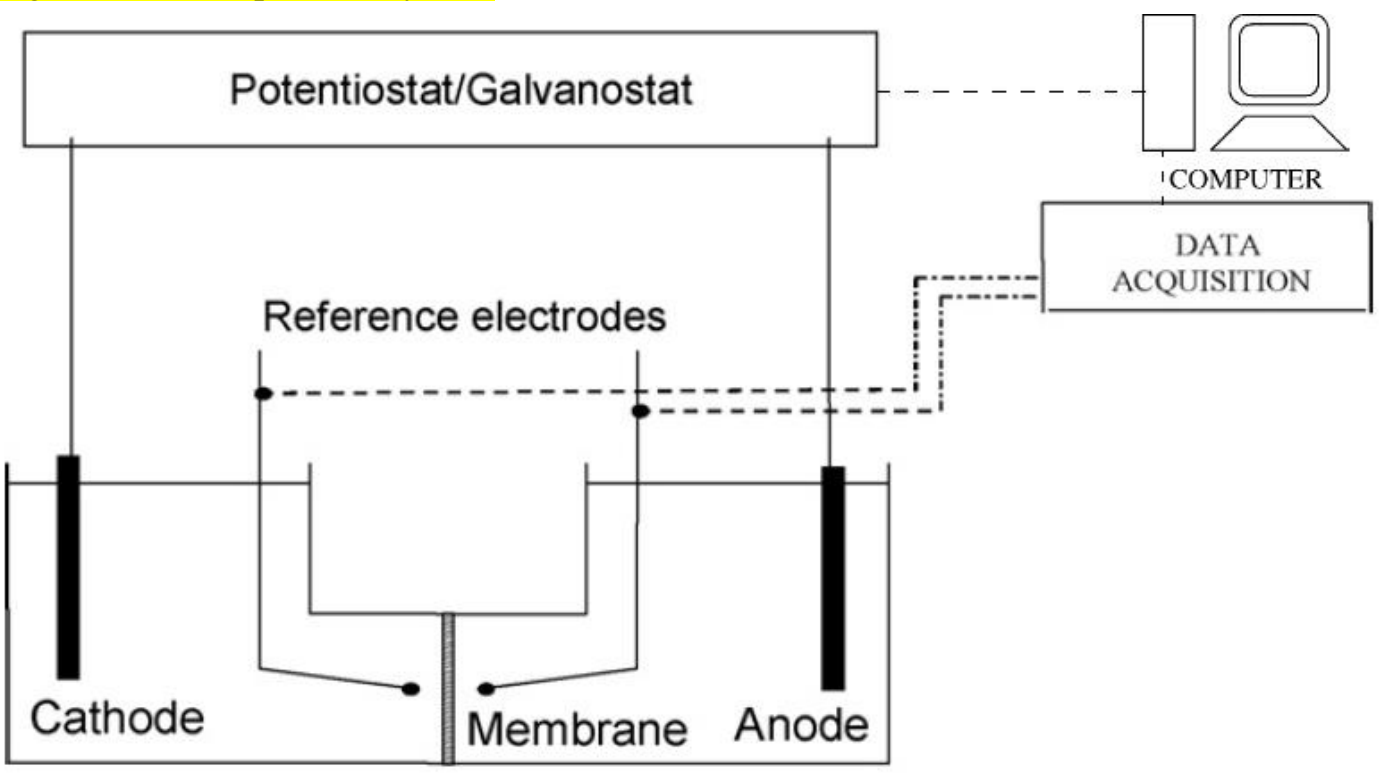

Figure 1: Schematic diagram of the two-compartment electrochemical cell.

Before each experimental test, the membranes were equilibrated by immersion in solutions, of the same concentrations as those required in the experiments, which were kept under stirring for 24 hours. After this time, the membranes were assumed to be in equilibrium with the ions present in the solution and ready for use in the experiments.

In the experimental tests, the imposed current promoted ion movement owing to the electric field created in the electrodialytic cell: the ions with an electronegative charge $\left(\mathrm{CrO}_{4}^{2-}\right.$, $\mathrm{HCrO}_{4}^{-}, \mathrm{Cr}_{2} \mathrm{O}_{7}{ }^{2-}$, and $\mathrm{SO}_{4}{ }^{2-}$ ) moved towards the anode, whereas the nickel present in the cationic $\mathrm{Ni}^{2+}$ form and the protons provided by the chromic acid were transferred through the membrane to the cathodic compartment.

\section{Results}

\subsection{Evolution of zirconium phosphate characteristics with temperature}

The HT-XRD mineralogical characterisation showed that the zirconium phosphate precipitate comprised three crystalline phases: $\mathrm{Zr}\left(\mathrm{HPO}_{4}\right)_{2} \cdot \mathrm{H}_{2} \mathrm{O}(\mathrm{HOPZr}), \mathrm{H}_{2} \mathrm{Zr}\left(\mathrm{PO}_{4}\right)_{2}$ (HPZr), and $\mathrm{ZrP}_{2} \mathrm{O}_{7}(\mathrm{PZr})$. It further showed that the mineralogical composition changed as temperature increased (Figure 2), without any sign of a glassy halo being detected in the diffractograms, which would signal the presence of amorphous phase. Since the intensity of 
the reflection $I_{100}$ of the three identified crystalline phases enabled the evolution of each phase to be estimated (Figure 3), it was inferred that HOPZr and HPZr decomposed and transformed into $\mathrm{PZr}$ when the temperature was progressively raised, $\mathrm{PZr}$ being the only crystalline phase present above $300^{\circ} \mathrm{C}$. However, this phase underwent changes when the temperature was raised further, as the intensity of the reflections increased up to the range $\left[500^{\circ} \mathrm{C}, 600^{\circ} \mathrm{C}\right]$, beyond which a slight decrease occurred. This result agrees in general with that described by Trobajo et al. [19].

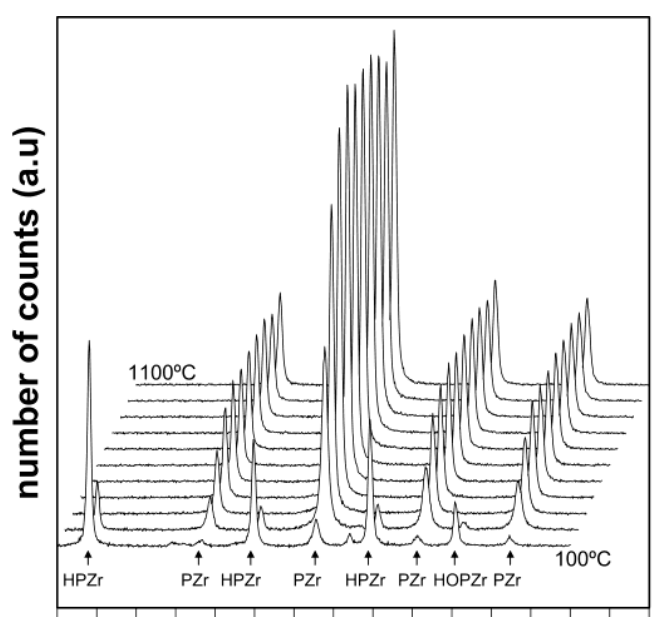

15161718192021222324252627282930 $2 \theta\left({ }^{\circ}\right)$

Figure 2: Detail of the HT-XRD diffractograms of the zirconium phosphate precipitate obtained in the range between $100^{\circ} \mathrm{C}$ and $1100^{\circ} \mathrm{C}$ with a spacing of $100^{\circ} \mathrm{C}$.

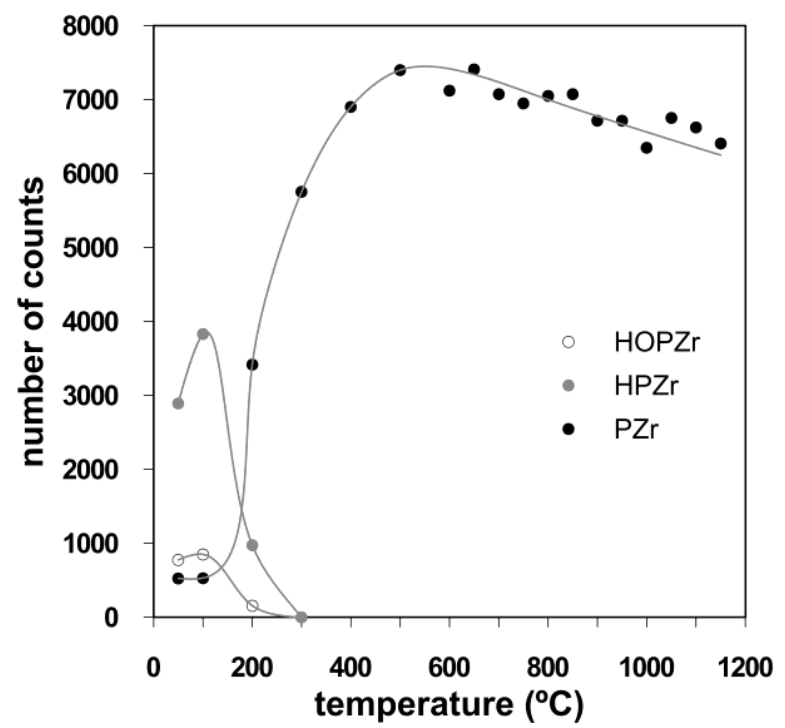

Figure 3: Evolution of the intensities of the most important reflections of the HOPZr, HPZr, and PZr phases with temperature.

The evolution of the ion-exchange capacity of the samples obtained when the zirconium phosphate precipitate was treated at increasing temperatures exhibited three differentiated sections: when $\mathrm{T}_{\mathrm{c}}$ was raised from $110^{\circ} \mathrm{C}$ to $250^{\circ} \mathrm{C}$, the exchange capacity decreased; from 
$250^{\circ} \mathrm{C}$ to $550^{\circ} \mathrm{C}$ the exchange capacity increased; and finally beyond $550^{\circ} \mathrm{C}$ it decreased markedly (Figure 4). This evolution differed from the decrease in the IEC with the increase in $T_{C}$ described previously $[28,29]$. The observed behaviour could be related to differences in the mineralogical composition of the samples generated at each temperature, as well as to sample structural variations, since studies have reported the difficulty of obtaining zirconium phosphate with a reproducible structure $[19,30]$.

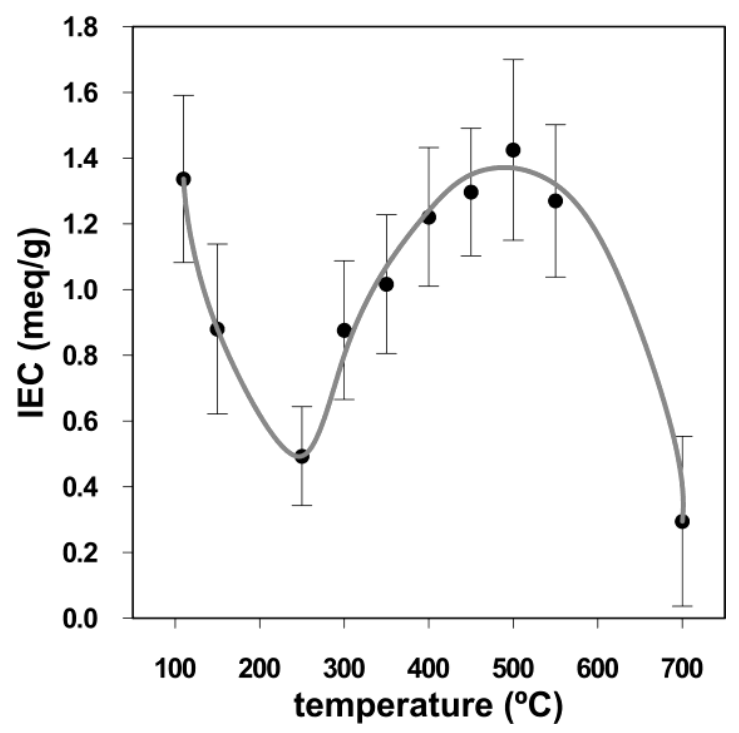

Figure 4: Evolution of the zirconium phosphate precipitate ion-exchange capacity as a function of the maximum thermal treatment temperature.

TG-EGA analysis allows the evolution of the IEC to be interpreted. Four clear mass losses were identified in the temperature ranges in which the structural changes occurred (Figure 5). The first two may be associated with HPZr and HOPZr decomposition, but those occurring above $300^{\circ} \mathrm{C}$ could not be interpreted from the XRD data. In addition, the mass loss displayed a complex profile in the range $\left[300^{\circ} \mathrm{C}, 700^{\circ} \mathrm{C}\right]$ since, together with two clear decompositions defined at $400^{\circ} \mathrm{C}$ and $600^{\circ} \mathrm{C}$, there was a quite small progressive decomposition that continued even above $700^{\circ} \mathrm{C}$. The mass losses at high temperature were associated by Trobajo et al. [19] with the presence of solid phosphoric acid in the zirconium phosphate obtained by precipitation, a substance that would be eliminated at temperatures above its boiling point $\left(400^{\circ} \mathrm{C}\right)$. However, the EGA only detected a signal corresponding to a mass/charge ratio of 18 , even though a mass/charge ratio up to 142 was investigated, demonstrating that the only species produced by the successive decompositions was water. This meant that none of the other species that might have been present, based on the raw materials used in the synthesis (such as $\mathrm{Cl}_{2}, \mathrm{HCl}, \mathrm{H}_{3} \mathrm{PO}_{4}$, and $\mathrm{P}_{2} \mathrm{O}_{5}$ ), had been generated in the decompositions that were successively identified. 


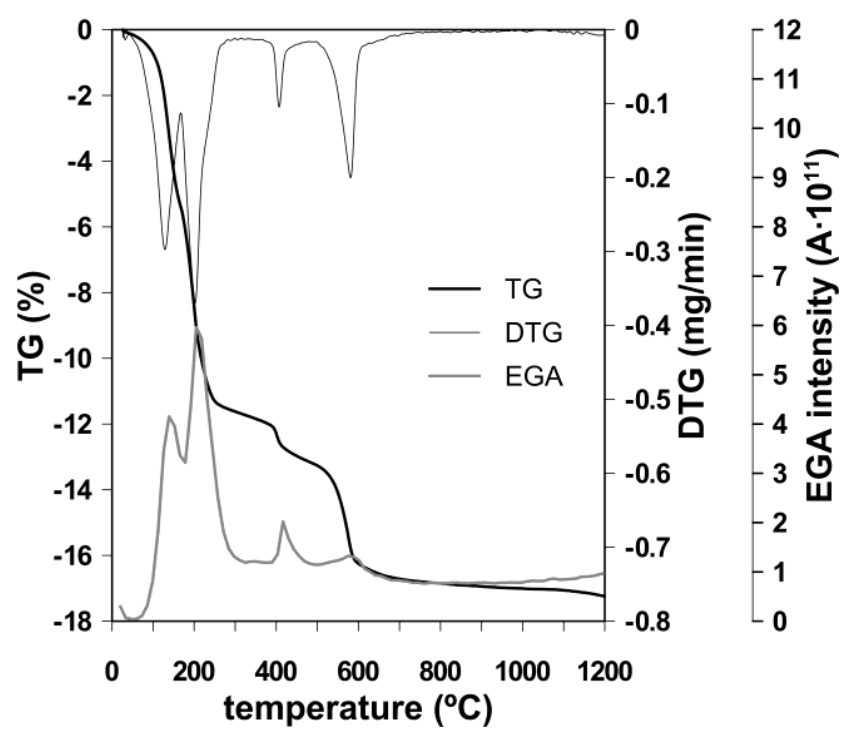

Figure 5: TG-DTG-EGA analysis of the zirconium phosphate precipitate.

The results suggest that the reduction of the IEC between room temperature and $250^{\circ} \mathrm{C}$ was due to decomposition of the HOPZr and HPZr phases, which had exchangeable protons in the structure. This is consistent with the data reported by Thakkar et al. [28,29]. However, the solid obtained may be assumed still to contain a certain quantity of $\mathrm{OH}$ groups, possibly close to the particle surface because their presence did not involve a modification in the crystalline structure of PZr, but they were stabilised in some way, since the IEC was very small. The increase in the IEC between $250^{\circ} \mathrm{C}$ and $450^{\circ} \mathrm{C}$ may be assumed to be related to the partial loss of water produced by the destabilisation of the $\mathrm{OH}$ groups, the remaining $\mathrm{OH}$ groups being responsible for the ion exchange. On the other hand, the decomposition at $600^{\circ} \mathrm{C}$ may be assumed to entail the practical disappearance of these $\mathrm{OH}$ groups when they recombined to generate more water.

The results obtained indicate that the optimum maximum temperature for fixing zirconium phosphate on the ceramic support was in the range $\left[450^{\circ} \mathrm{C}, 550^{\circ} \mathrm{C}\right]$, since this provided a high zirconium phosphate ion-exchange capacity and better bonding to the ceramic support than at lower temperatures. It was decided to use the temperature corresponding to the lower limit of this range in membrane synthesis, in order to reduce the energy costs in a subsequent process scale-up.

\subsection{Characterisation of the cation-exchange membrane}

The synthesised cation-exchange membranes were characterised from a microstructural and an electrochemical viewpoint, and their characteristics were compared with those of the porous ceramic used as a support (hereafter CEM and support, respectively).

The electron microscopy comparison of polished cross-sections identified some nanometresized crystals distributed inside the CEM porous network, which were not present in the 
support (Figure 6). EDX confirmed the absence of $\mathrm{Zr}$ and $\mathrm{P}$ in the support and their presence throughout the thickness of the CEM. The strongest $\mathrm{Zr}$ and $\mathrm{P}$ signals were at the positions of the crystals (Figure 7) and it was therefore inferred that they corresponded to zirconium phosphate. On the other hand, the mercury intrusion measurements indicated that the CEM displayed a lower total pore volume, its pore size distribution being shifted towards smaller diameters with respect to that of the support (Figure 8).

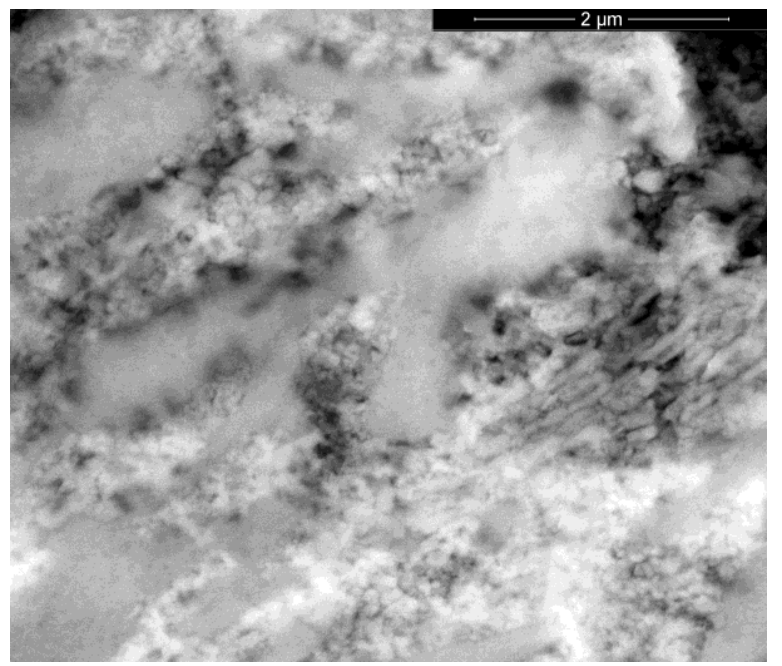

Figure 6: SEM image of a CEM polished cross-section showing the ZrP nanocrystals (white crystals).

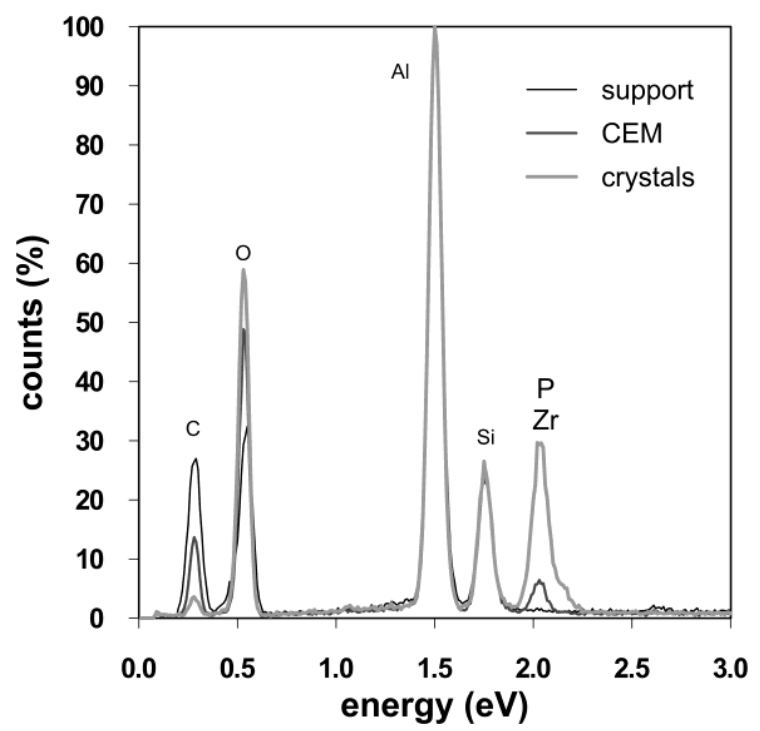

Figure 7: EDX spectra of the ceramic support, the CEM, and the white crystals shown in Figure 6. 


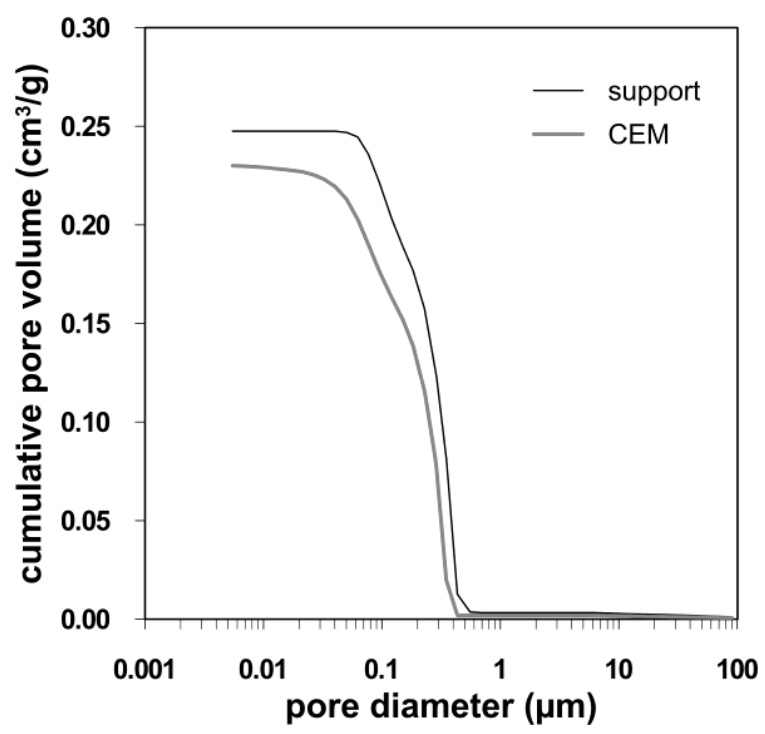

Figure 8: Pore size distribution of the support and the CEM.

The above results demonstrate that the procedure used allowed zirconium phosphate to be deposited and fixed in the ceramic support, yielding a cation-exchange membrane.

In order to compare the electrochemical behaviour of the support with that of the CEM, the membrane intensity-potential or polarisation curves were first obtained. The polarisation curves exhibited a linear behaviour, which differed from the behaviour obtained with polymeric ion-exchange membranes in which a limit intensity was reached. The ceramic membranes therefore displayed an ohmic behaviour, there being no limits with regard to the applied current density.

The polarisation curve data were used to perform galvanostatic experiments (at constant intensity) using a two-compartment cell, and ion transport through the two ceramics was studied from the anodic to the cathodic compartment with a view to eliminating $\mathrm{Ni}^{2+}$ from the anodic compartment and obtaining a $\mathrm{Cr}_{2} \mathrm{O}_{7}{ }^{=}$purified solution that could be reused. Experiments were conducted at several work intensities with various $\mathrm{Ni}^{2+}$ and $\mathrm{Cr}_{2} \mathrm{O}_{7}{ }^{=}$ concentrations. The concentrations used were chosen in accordance with typical rinse bath concentrations; the work intensities were chosen from the polarisation curves and, as the ceramics displayed no limit current density, the values of the applied intensity were chosen such that the two ceramics could be compared with polymeric membranes that exhibited a limit current density.

In Figure 9, the polarisation curves of the ceramic CEM and those of a polymeric CEM (Nafion ${ }^{\circledR} 117$ ) are compared in a solution of $10^{-2} \mathrm{M} \mathrm{NiSO}_{4}$ and $\mathrm{Cr}_{2} \mathrm{O}_{7}{ }^{2}$, and $10^{-3} \mathrm{M} \mathrm{H}_{2} \mathrm{SO}_{4}$. As can be seen in this figure, the polarisation curve of the polymeric CEM shows the three characteristic regions of these kind of membranes: a quasi-ohmic variation in the lower voltage range, followed by a plateau from which the value of the limiting current, $\mathrm{I}_{\mathrm{lim}}$, is defined, and then, an increase of the current intensity [31,32]. However, the polarisation 
curve of the ceramic CEM shows a linear behavior. This means that in the case of the ceramic membrane there is no limitation on the applied current intensity. Furthermore, as shown in Figure 9, for low currents, the resistance of the ceramic membrane is greater than the resistance of the polymeric membrane, but for large currents, the resistance of the ceramic membrane is lower than the resistance of the polymeric membrane. Therefore, in the case of the ceramic membranes higher cation transfer rates could be achieved at lower energy consumptions than with the polymeric membranes, if operated at high currents."

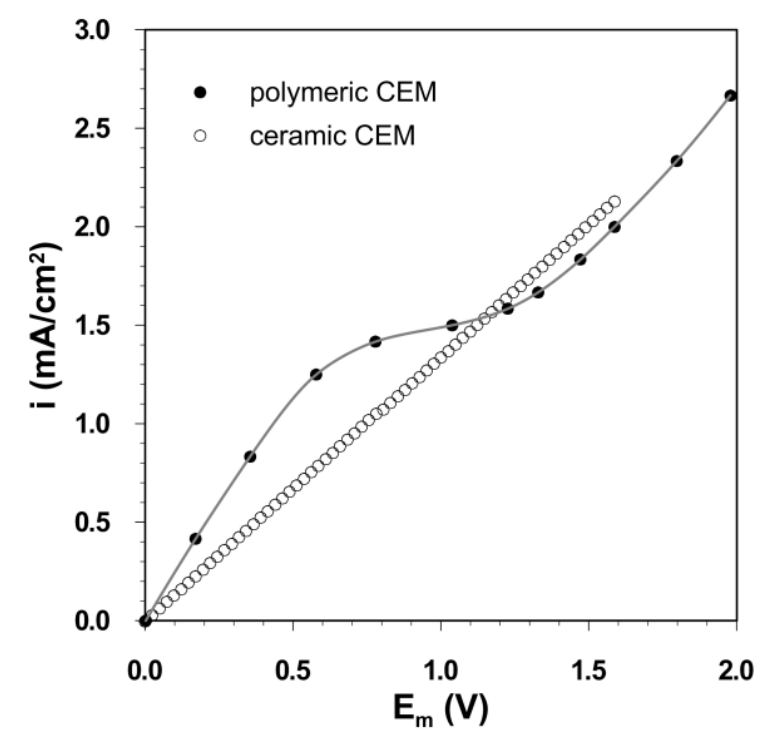

Figure 9: Comparison of the polarization curves of the polymeric CEM and the ceramic CEM

The evolution of the fractions of $\mathrm{Ni}^{2+}$ and $\mathrm{Cr}_{2} \mathrm{O}_{7}{ }^{=}$removed from the anodic compartment through the support and the CEM $\left(\mathrm{X}_{\mathrm{Ni}}\right.$ and $\mathrm{X}_{\mathrm{Cr}}$ respectively), at a working current intensity of $0.01 \mathrm{~A}$ and initial concentrations of $10^{-2} \mathrm{M}$ in Ni ${ }^{2+}$ and $\mathrm{Cr}_{2} \mathrm{O}_{7}{ }^{=}$and $10^{-3} \mathrm{H}_{2} \mathrm{SO}_{4}$ in the anodic compartment, and $10^{-3} \mathrm{H}_{2} \mathrm{SO}_{4}$ in the cathodic compartment, is plotted in Figures 10 and 11. The plots show that the fraction of $\mathrm{Ni}^{2+}$ removed from the anodic compartment increased practically parabolically with time and the value reached was similar for the support and for the CEM. On the other hand, though the fraction of $\mathrm{Cr}_{2} \mathrm{O}_{7}{ }^{=}$removed from the anodic compartment increased with time, it was much smaller than the fraction of $\mathrm{Ni}^{2+}$ removed, and the value reached in the CEM was smaller than that in the support. 


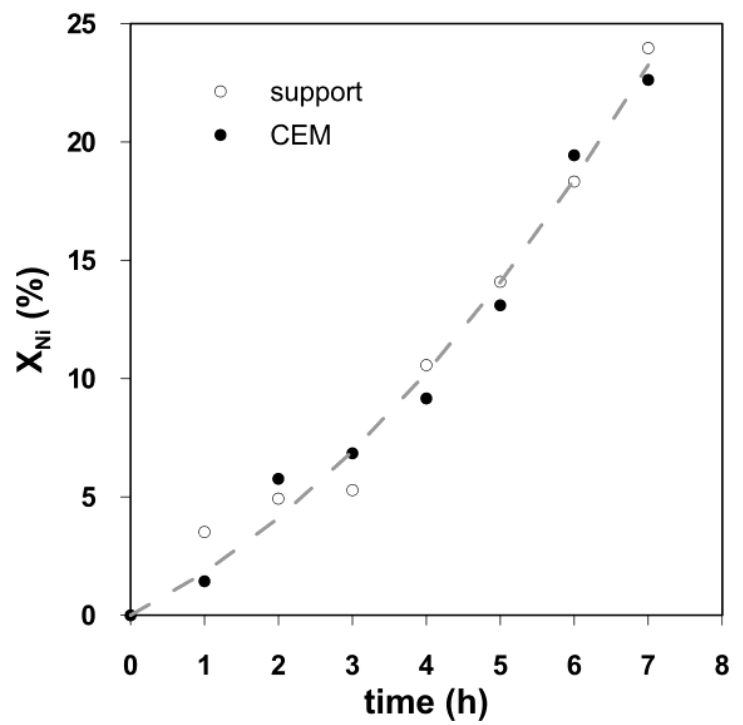

Figure 10: Evolution with time of the eliminated nickel fraction in the galvanostatic testing of the support and the CEM.

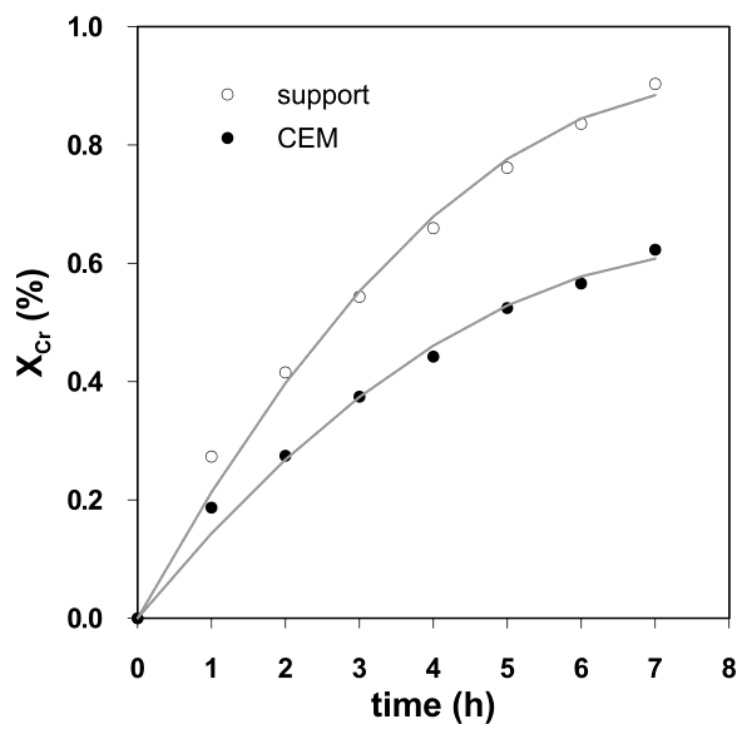

Figure 11: Evolution with time of the eliminated chromium fraction in the galvanostatic testing of the support and the CEM.

These results may be explained by considering the different transport mechanisms of $\mathrm{Ni}^{2+}$ and $\mathrm{Cr}_{2} \mathrm{O}_{7}{ }^{=}$through the two ceramics, and the characteristics of those ceramics. On the one hand, $\mathrm{Ni}^{2+}$ transport from the anodic compartment to the cathodic compartment through the ceramics occurred mainly by migration and depended fundamentally on the applied intensity and the solution composition, so that the values obtained were similar for the support and the CEM. In addition, the voltage reached was very similar in both cases, hence producing similar energy consumption. However, $\mathrm{Cr}_{2} \mathrm{O}_{7}{ }^{=}$transport through the membranes may be assumed mainly to occur by diffusion through the porous network, owing to the concentration gradient existing on both sides of the membrane. It is this difference in 
transport mechanism that presumably made the eliminated $\mathrm{Cr}_{2} \mathrm{O}_{7}{ }^{=}$fraction much smaller than the eliminated $\mathrm{Ni}^{2+}$ fraction. On the other hand, it may be observed that $\mathrm{Cr}_{2} \mathrm{O}_{7}{ }^{=}$transport was lower in the case of the CEM, essentially because of its selectivity, since the porosity of the two membranes was similar (the total pore volume of the CEM was only 7\% lower than that of the support).

It may be concluded, therefore, that the synthesised CEM exhibited a greater rejection to the anions, though this rejection was not entirely due to the existing concentration gradient between the two reactor compartments. This rejection may be essentially attributed to the presence of zirconium phosphate, which provided selectivity and hardly reduced CEM porosity with respect to that of the support. In addition the zirconium phosphate enhanced the conductivity, since the voltage reached in both cases was very similar even though the CEM was slightly less porous.

\section{Conclusions}

The study showed that the ion-exchange capacity of the zirconium phosphate synthesised by precipitation from zirconyl chloride and phosphoric acid exhibited a complex evolution with temperature, characterised by two maximum values: a first maximum value at about $100^{\circ} \mathrm{C}$ and a second one in the range between $450^{\circ} \mathrm{C}$ and $550^{\circ} \mathrm{C}$. The first maximum value was due to the presence of the hydrated phases $\mathrm{Zr}\left(\mathrm{HPO}_{4}\right)_{2} \cdot \mathrm{H}_{2} \mathrm{O}$ and $\mathrm{H}_{2} \mathrm{Zr}\left(\mathrm{PO}_{4}\right)_{2}$, while the second appeared to be due to a variant of zirconium phosphate whose diffractogram corresponded to anhydrous $\mathrm{ZrP}_{2} \mathrm{O}_{7}$, but which released $\mathrm{H}_{2} \mathrm{O}$ up to about $600^{\circ} \mathrm{C}$. This variant probably contained $\mathrm{OH}$ groups in its structure, which provided the ion-exchange capacity at high temperature.

The zirconium phosphate was precipitated in the porous network of a ceramic support and satisfactory bonding was achieved between both, without losing the ion-exchange capacity, by means of a thermal cycle whose maximum temperature was in the identified optimum range $\left(450^{\circ} \mathrm{C}\right)$. The resulting membrane was selective to the cations typically found in the spent rinse water of chromium plating processes, so that it could be used in the electrodialysis treatment of these effluents.

\section{Acknowledgements}

The authors wish to express their gratitude to the Spanish Ministry of Science and Innovation for the support given to the research study (National Basic Research Programme, Ref. CTQ2008-06750-C02-02), as well as for the FPU student grant awarded to one of the authors (Ref: AP2009-4409). 


\section{References}

[1] H. Strathmann, in: E. Drioli, L. Giorno, Comprehensive membrane science and engineering, Vol. 2, Elsevier, Oxford, 2010, pp391-428.

[2] E. Drioli, E. Fonananova, in: E. Drioli, L. Giorno, Membrane operations: innovative separations and transformations, Wiley-VCH, Weinheim, 2009, pp265-284.

[3] H. Strathmann, in: E. Drioli, L. Giorno, Membrane operations: innovative separations and transformations, Wiley-VCH, Weinheim, 2009, pp83-120.

[4] G. Alberti, M. Casciola, U. Costantino, G. Levi, Inorganic ion exchange membranes consisting of microcrystals of zirconium phosphate supported by Kynar, J. Membr. Sci. 3 (1978) 179-190.

[5] R. Semiat, D. Hasson, in: E. Drioli, L. Giorno, Membrane operations: innovative separations and transformations, Wiley-VCH, Weinheim, 2009, pp221-244.

[6] J.I. Bregman, R.S. Braman, Inorganic ion exchange membranes, J. Colloid Sci. 20 (1965) 913-922.

[7] H.K. Bishop, J.A. Bittles, G.A. Guter, Investigation of inorganic ion exchange membranes for electrodialysis, Desalination, 6 (1969) 369-380.

[8] K.S. Rajan, D.B. Boies, A.J. Casolo, J.I. Bregman, Inorganic ion exchange membranes and their application to electrodialysis, Desalination 1 (1966) 231-246.

[9] Inamuddin, S.A. Khan, W.A. Siddiqui, A.A. Khan, Synthesis, characterization and ionexchange properties of a new and novel organic-inorganic hybrid cation exchanger: Nylon6,6, Zr(IV) phosphate, Talanta 71 (2007) 841-847.

[10] M. Helen, B. Viswanathan, S.S. Murthy, Synthesis and characterization of composite membranes based on $\alpha$-zirconium phosphate and silicotungstic acid, J. Membr. Sci. 292 (2007) 98-105.

[11] Yu.S. Dzyaz'ko, V.N. Belyakov, N.V. Stefanyak, S.L. Vasilyuk, Anion-exchange properties of composite ceramic membranes containing hydrated zirconium dioxide, Russ. J. Appl. Chem. 79 (2006) 769-773.

[12] Linkov, V.M., Belyakov, V.N. Novel ceramic membranes for electrodialysis, Sep. Purif. Technol. 25 (2001) 57-63.

[13] V.M. Linkov, Yu.S. Dzyaz'ko, V.N. Belyakov, V.Yu. Atamanyuk, Inorganic composite membranes for electrodialytic desalination, Russ. J. Appl. Chem. 80 (2007) 576-581.

[14] M.R. El-Sourougy, E.E. Zaki, H.F. Aly, Transport characteristics of ceramic supported zirconium phosphate membrane, J. Membr. Sci. 126 (1997) 107-113. 
[15] E. Sánchez, S. Mestre, V. Pérez-Herranz, M. García-Gabaldón, Síntesis de membranas cerámicas para la regeneración de baños de cromado agotados, Bol. Soc. Esp. Ceram. Vidr. 44 (2005) 409-414.

[16] E. Sánchez, S. Mestre, V. Pérez-Herranz, H. Reyes, E. Añó, Membrane electrochemical reactor for continuous regeneration of spent chromium plating baths, Desalination 200(1-3) (2006), 668-670.

[17] G. Alberti, M. Casicola, U. Constantino, R. Vivani, Layered and pillared metal (IV) phosphates and phosphonates, Adv. Mater. 8(4) (1996) 291-303.

[18] G. Alberti, E. Torracca, Crystalline insoluble salts of polybasic metals-II. Synthesis of crystalline zirconium or titanium phosphate by direct precipitation, J. Inorg. Nucl. Chem. 30 (1968) 317-318.

[19] C. Trobajo, S.A. Khinakov, A. Espina, J.R. García, On the synthesis of $\alpha$-zirconium phosphate, Chem. Mater. 12 (2000) 1787-1790.

[20] G. Alberti, Synthesis, crystalline structure and insoluble ion-exchange properties of acid salts of tetravalent metals and their salt forms, Acc. Chem. Res. 11 (1978) 163-170.

[21] A.O. Rajeh, L. Szirtes, Investigations of crystalline structure of gamma-zirconium phosphate. J. Radioanal. Nucl. Chem, 195(2) (1995) 319-322.

[22] A.M.K. Andersen, Preparation and characterization of a new 3-dimensional zirconium hydrogen phosphate, $\tau-\mathrm{Zr}\left(\mathrm{HPO}_{4}\right)_{2}$. Determination of the complete crystal structure combining synchrotron X-ray single-crystal diffraction and neutron powder diffraction, Inorg. Chem. 37(1998) 876-881.

[23] Y. Feng, W. He, X. Zhang, W. Jia, H. Zao, The preparation of nanoparticle zirconium phosphate, Mater. Lett. 61(2007) 3258-3261.

[24] A. Clearfield, Inorganic ion exchangers, past, present and future, Solvent Extr. Ion Exch. 18(4) (2000) 655-678.

[25] L. Szirtes, S.K. Shakshooki, A.M. Szeleczky, A.O. Rajeh, Thermoanalytical investigation of some layered zirconium salts and their various derivatives I, J. Thermal Anal. 51 (1998) 503-515.

[26] A. Al-Othman, A.Y. Tremblay, W. Pell, S. Letaief, T.J. Burchell, B.A. Peppley, M. Ternan, Zirconium phosphate as the proton conducting material in direct hydrocarbon polymeric electrolyte membrane fuel cells operating above the boiling point of water, J. Power Sources 195 (2010) 2520-2525.

[27] M. Helen, B. Viswanathan, S.M. Srinivasa, Synthesis and characterization of composite membranes based on $\alpha$-zirconium phosphate and silicotungstic acid, J. Membr. Sci. 292 (2007) 98-105. 
[28] R. Thakkar, U. Chudasama, Synthesis, characterization and proton transport property of crystalline-zirconium titanium phosphate, a tetravalent bimetallic acid salt, J. Sci. Ind. Res. 68 (2009) 312-318.

[29] R. Thakkar, H. Patel, U. Chudasama, A comparative study of proton transport properties of zirconium phosphate and its metal exchanged phases, Bull. Mater. Sci. 30 (2007) 205209.

[30] P. Jiang, B. Pan, W. Zhang, Q. Zhang, A comparative study on lead sorption by amorphous and crystalline zirconium phosphates, Colloids Surf., A. 322 (2008) 108-112.

[31] M. García-Gabaldón, V. Pérez-Herranz, J. García-Antón, J.L. Guiñón. Use of ionexchange membranes for the removal of tin from spent activating solutions. Desal. Wat. Treat.3 (2009) 150-156.

[32] M. García-Gabaldón, V. Pérez-Herranz, J. García-Antón, J.L. Guiñón. Effect of hydrochloric acid on the transport properties of tin through ion-exchange membranes. Desal. Wat. Treat. 10 (2009) 73-79. 